\title{
Bilateral asymmetry in the mass and size of otolith of two cichlid species collected from Lake Ahémé and Porto-Novo Lagoon (Bénin, West Africa)
}

Laith Jawad', Pierre Gnohossou² \& Ayoko Géraldine Tossou ${ }^{2}$

1 Pokeno, Auckland 2471, New Zealand

2 Département d'Aménagement et Gestion de Ressources Naturelles, Faculté d"Agronomie, University of Parakou, BP 123

Parakou, Republic of Benin.

Correspondence

L. Jawad

E-mail: laith_jawad@hotmail.com

Received: 3 May 2019

Accepted: 18 December 2019

Published on-line: 25 March 2020

\section{Resumen}

Asimetría bilateral en la masa y el tamaño de otolitos de dos especies de cíclidos capturados en el lago Ahémé y la laguna de Porto Novo (Benín, África Occidental)

Se estudia la asimetría de la masa del otolito sacular en dos especies de peces cíclidos Sarotherodon melanotheron y Coptodon guineensis recolectadas del lago Ahémé y la laguna Porto-Novo, Benín, África occidental. La longitud y el ancho de los otolitos de especímenes adultos de ambas especies se usaron para calcular la asimetría fluctuante en estos dos caracteres. Los resultados muestran que el nivel de asimetría del ancho del otolito es el más importante. La posible causa de la asimetría en estas especies se ha discutido en relación con diferentes contaminantes en el área. Nuestros datos no muestran diferencias significativas, aunque varios estudios demostraron una asimetría más alta en individuos más grandes (de más edad).

Palabras clave: Factores ecológicos; Contaminación acuática; Cichlidae; Sarotherodon melanotheron; Coptodon guineensis.

\begin{abstract}
Saccular otolith mass asymmetry is studied in two cichlid fish species Sarotherodon melanotheron and Coptodon guineensis collected from Lake Ahémé and Porto-Novo Lagoon, Bénin, West Africa. The length and width of otoliths from adult specimens of both species were used to calculate the fluctuating asymmetry in these two characters. The results show that the level of asymmetry of the otolith width is the most important. The possible cause of the asymmetry in these species has been discussed in relation to different pollutants in the area. Our data show no significant difference, although several studies proved a higher asymmetry in larger (older) individuals.
\end{abstract}

Key words: Ecological factors; Water pollution; Cichlidae; Sarotherodon melanotheron; Coptodon guineensis. 


\section{Introduction}

Among the interesting character of the vertebrate inner ear is the presence of statolithic organs that are linked to hearing and gravity. In fishes, the statoliths are compacted and can thus be easily measured (Anken et al. 1998). Otoliths have played a vital role in fisheries science for many years (Kingsmill 1993), and reliable methods to determine the size of a given otolith as a parameter of its mass are readily available (Alemany \& Alvarez 1994).

It has been well documented that variation in the shape of fish otoliths is affected by external factors, e.g. environmental conditions, or individual characteristics, e.g. the individual genotype or state, but the possible intra-individual cause of variation, specifically the difference in otolith shape between the right and left inner ears (referred to as otolith location side), are poorly studied (Mille et al. 2015). Under normal conditions, the three orthogonal semicircular otoliths at both sides of the head are morphologically similar in roundfishes (Panfili et al. 2002), although there are some inter-specific modifications in the size and shape (Popper \& Lu 2000). A typical bilateral asymmetry of the otoliths is clearly seen in flatfish species, which endure profound asymmetric morphological changes throughout their lives, including a cranial distortion and the relocation of one eye to the other side of the head (Bao et al. 2011).

The studies were few on the otolith asymmetry of the freshwater fish (e.g., Downhower et al. 1990, Østbye et al. 1997, Anken et al. 1998, Øxnevad et al. 2002, Novak et al. 2013) in general and the otolith mass asymmetry in particular (e.g., Scherer et al. 2001, Takabayashi \& OhmuraIwasaki 2003, Lychakov et al. 2006, Yedier et al. 2018). The researchers on the otolith mass asymmetry of the freshwater fishes have reached to a conclusion that the differences in weight of the otolith found on both sides of the fish head is either large (Scherer et al. 2001) or small as suggested by the work of Takabayashi \& OhmuraIwasaki (2003). The latter work was based on members of the family Cyprinidae, where the sgitta otolith is very small and the asteriscus otolith is the largest among the three otoliths found in the inner ear of the fish.

The asymmetry in the otolith mass can have a negative impact on the life of a fish, particularly on the hearing and the balance (Lychakov et al.
2008). It has been employed as a bio-indicator to check the state between different aquatic habitats (Grønkjær \& Sand 2003) and it was also used to test different environmental effects in fish populations. The most obvious effect of a bilateral asymmetry in fish otolith mass is an abnormal swimming activity (Helling et al. 2003) and intrusion with precise sound localization resulting in failure of individuals to mix with the habitat they are living in (Lychakov \& Rebane 2005). Gagliano et al. (2008) investigated whether otolith asymmetry influenced the capability of returning larvae to detect and effectively recruit to favorable reef habitats and they found that larvae with asymmetrical otoliths not only faced greater troubles in identifying appropriate settlement niches, but may also risk considerably higher rates of mortality. They also concluded that otolith asymmetries occurring early in the embryonic stage were not modified by any compensational growth mechanism during the larval stage as these changes are permanent and that phenotypic selection is disturbed by asymmetrical individuals. Hence, asymmetry is likely to play a vital role in the dynamics of wild fish populations.

The natural dispersal of Sarotherodon melanotheron Rüppell, 1852 and Coptodon guineensis (Günther, 1862) is limited to West Africa, Benin (Froese \& Pauly 2018). The presence of S. melanotheron in Mauritania is doubtful and it has not been introduced to any other country in the world (Froese \& Pauly 2018). C. guineensis, however, was introduced in several countries, e.g. Cambodia (Kottelat 1985), the United States of America (Welcomme 1988), Hawaii (Yamamoto 1992) and Surinam (Kullander \& Nijssen 1989), where it has become an established species. The latter species is not considered established in other countries such as Japan and Russia (Welcomme 1988).

An earlier study on bilateral asymmetry in $S$. melanotheron and $C$. guineensis from Lake Ahémé and Porto-Novo Lagoon is that of Jawad et al. (2016), which did not consider the otoliths. The present study aims at examining the level of bilateral asymmetry in the mass and size of the otoliths in these freshwater species and, consequently, delivers the first data on this subject.

\section{Materials and methods}

\section{Study Area and Sampling Sites}

Two sites were sampled: Lake Ahémé and Porto- 
Novo Lagoon. Lake Ahémé is situated in southern Benin between $6.20^{\circ}-6.40^{\circ} \mathrm{N}$ and between $1.55^{\circ}$ $2.00^{\circ} \mathrm{E}$ (Fig. 1). The lake mainly obtains its freshwater input from the Couffo River, its surface area is about $\sim 78 \mathrm{~km}^{2}$ in the dry season and $\sim 100 \mathrm{~km}^{2}$ in the wet season (Dissou 1986). It is $24 \mathrm{~km}$ long, the northern part is deeper than the southern and it is connected to the sea by the $10 \mathrm{~km}$ long Aho channel. Throughout the dry season, the sea water runs into this channel, producing an increase in water salinity in the southern part of the lake (Niyonkuru \& Lalèyè, 2012). Porto-Novo Lagoon $\left(6^{\circ} 25 \mathrm{~N}, 2^{\circ} 38 \mathrm{E}\right)$ is found south of the political capital Porto-Novo (Fig. 1). It is triangular in shape with an area of $\sim 30 \mathrm{~km}^{2}$ in the wet season and $\sim 20 \mathrm{~km}^{2}$ in other seasons. Its length is $6 \mathrm{~km}$ and its width varies between $2-4 \mathrm{~km}$. It is linked to the Lagos Lagoon (Nigeria) in the east and to Nokoue Lake in the west. The salinity of the water in the lagoon differs from oceanic via tidal influence to freshwater via several tributaries (Adandédjan et al. 2011).

\section{Fish collection}

Fish specimens were attained from each locality, collected by fishermen. For the squared coefficient asymmetry, 33 individuals of each species were used from Lake Ahémé and 43 individuals

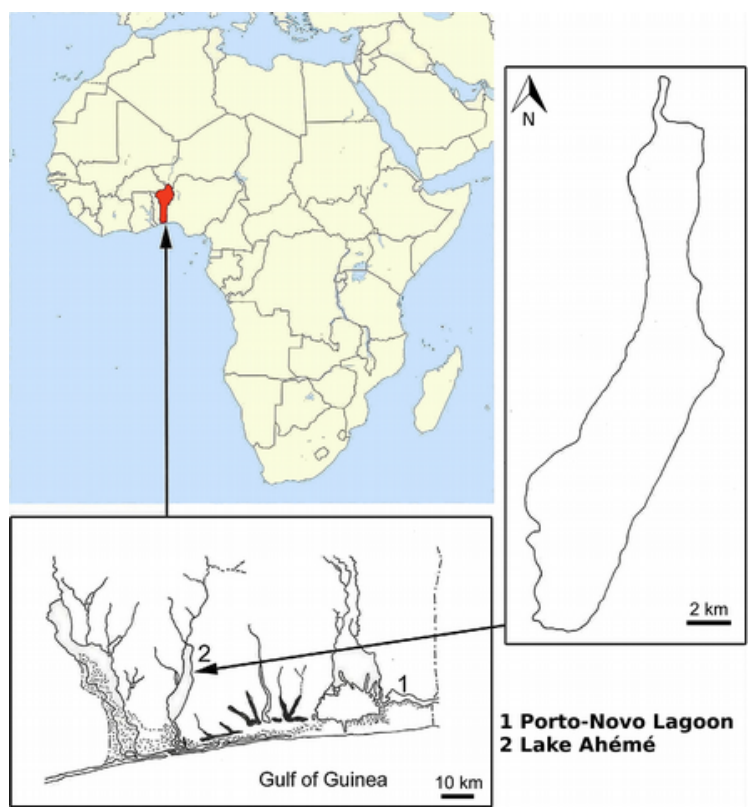

Figura 1. Mapa mostrando los puntos de captura de Sarotherodon melanotheron and Coptodon guineensis en el lago Ahémé y la laguna de Porto-Novo, Benín.

Figure 1. Map showing capture points of Sarotherodon melanotheron and Coptodon guineensis in Lake Ahémé and Porto-Novo Lagoon, Bénin. of each species from Porto-Novo Lagoon. Multimesh gillnets $(200 \mathrm{~m} \mathrm{x} 1.30 \mathrm{~m}, 25,40$ and $50 \mathrm{~mm}$ mesh) and cast nets (6 diameter, $20 \mathrm{~mm}$ mesh) were used to catch the fish. Lake Ahémé was sampled in August 2014 and Porto-Novo Lagoon in February 2015. The depth at all sampling sites ranged from 0.5 to $2.4 \mathrm{~m}$ (See Jawad et al. 2016). Juvenile fish, which were identified by the gonad stage, were not used in this study due to the incomplete development of their otoliths.

\section{Otolith mass asymmetry analysis}

Standard and total lengths were measured following the method of Jawad et al. (2016) preceding to removal of the otoliths. After the dissection of the auditory capsules, the otoliths were detached from each side, washed in distilled water, air-dried at room temperature for a few days, and then weighed on a Sartorius TE 313S analytical balance to accuracy of $0.0001 \mathrm{~g}$. Differences between left and right otolith mass values for each species was tested using t-test. Also, differences of otolith weight between males and females was tested $\mathrm{u}$ sing t-test.

The otolith mass asymmetry $(X)$ was computed from $X=(m r-m l) m^{-1}$, where $m r$ and $m l$ are the otolith masses of the right and left paired otoliths and $m$ is the mean mass of the right and left paired otoliths. In theory, the $X$ value can vary between 2 and $2, X=0$ represents the absence of mass asymmetry $(m r-m l)$, and $X=-2$ or $X=2$ represents the maximal asymmetry (absence of one otolith). A positive value of $X$ means a larger mass for the right otolith mass than the left whereas a negative value signifies the opposite. The relation between the absolute value of $X$ and the otolith growth rate was studied. The relationship between otolith mass and fish total length, $m=a l+b$, was calculated in order to assess the otolith growth rate, where $\mathrm{m}$ stands for the mass of the otolith, $l$ for the total length of the fish, $a$ for the coefficient characterizing the growth rate of the otolith, and $b$ for a constant for the species in question.

\section{Otolith size analysis}

Otolith length and width were measured to the nearest millimetre under a dissecting microscope. The differences between left and right otolith measurements (length and width) were tested using t-test. Also, differences of otolith sizes between males and females was tested using ttest for both species. 
The statistical analysis was based on the squared coefficient of the asymmetry variation $\left(\mathrm{CV}^{2}{ }_{\mathrm{a}}\right)$ for the two otolith dimensions according to Valentine et al. (1973):

$$
\mathrm{CV}^{2}{ }_{\mathrm{a}}=\left(\mathrm{S}_{\mathrm{r}-\mathrm{l}} * 100 / \mathrm{X}_{\mathrm{r}+1}\right)^{2}
$$

where $\mathrm{S}_{\mathrm{r}-\mathrm{l}}$ is the standard deviation of the signed differences and $X_{r+1}$ is the mean of the character, which is calculated by adding the absolute scores for both sides and divided by the sample size. Coefficients of asymmetry were compared between the populations of the two species using ANOVA tests.

\section{Results}

\section{Mass asymmetry of otolith}

\section{Lake Ahémé}

For $S$. melanotheron, the mean value of $\mathrm{X}$ is $0.0066 \pm 0.0223, \mathrm{n}=33$ (Fig. 2A) and the mean value of $|\mathrm{X}|$ is $0.0167 \pm 0.0133, \mathrm{n}=33$ (Fig. 2B). The difference of the mean otolith mass of $S$. melanotheron between both sides of the fish head in this lake was significant (t-test, $\mathrm{p}<0.05$ ). There were no differences in otolith weight between males and females (t-test, $\mathrm{p}>0.05$ ).

According to the regression analysis there was no relationship between fish total length and both $\mathrm{X}(\mathrm{y}=0.05 \mathrm{x}+0.0037)\left(\mathrm{p}>0.005, \mathrm{R}^{2}=0.0022\right)$ and $|\mathrm{X}|(\mathrm{y}=0.0001 \mathrm{x}-0.0082)\left(\mathrm{p}>0.05, \mathrm{R}^{2}=0.0784\right)$. The relation between the otolith mass difference ( $\mathrm{mr}$ $\mathrm{ml}$ ), and the fish length is more complex than the relation between $x$ and fish length $(n=33$, total length $=130-240 \mathrm{~mm}, \mathrm{p}>0.05, \mathrm{y}=0.05 \mathrm{x}-0.0014$, $\left.\mathrm{R}^{2}=0.0090\right)$ (Fig. 2C). For C. guineensis, the mean value of $\mathrm{x}$ is $0.0086 \pm 0.0133, \mathrm{n}=33$ (Fig. $3 \mathrm{~A}$ ) and the value of $|\mathrm{X}|$ is $0.0188 \pm 0.0143, \mathrm{n}=33$ (Fig. 3B). According to the regression analysis, there was no relationship between fish total length and both $\mathrm{X}$ $(\mathrm{y}=0.05 \mathrm{X}-0.0009)\left(\mathrm{p}>0.005, \mathrm{R}^{2}=0.0009\right)$ and $|\mathrm{X}|$ $(y=0.0001 X-0.0083) \quad\left(p>0.05, R^{2}=0.0613\right)$. The relation between the otolith mass difference ( $\mathrm{mr}$ $\mathrm{ml}$ ), and the fish length is more complex than the relation between $x$ and the fish length $(n=33$, total length $=130-240 \mathrm{~mm}, \quad \mathrm{p}>0.05, \mathrm{y}=0.05 \mathrm{x}-0.0001$, $\mathrm{R}^{2}=0.0025$ ) (Fig. 3C). In both species, the saccular otolith mass difference increases with the fish length.

\section{Porto-Novo Lagoon}

For $S$. melanotheron, the mean value of $\mathrm{X}$ is $0.0281 \pm 0.0123, n=43$ (Fig. 4A) and the mean value of $|\mathrm{X}|$ is $0.0127 \pm 0.0153, \mathrm{n}=43$ (Fig. 4B). The difference of the mean otolith mass of $S$. melanotheron between both sides of the fish head in this lagoon was significant (t-test, $\mathrm{p}<0.05$ ). There were no differences in otolith weight between males and females ( $t$-test, $\mathrm{p}<0$. 05) for both species from this lagoon.

According to the regression analysis, there was no relationship between the fish length, and both $X(y=0.05 X-0.0079)\left(p>0.005, R^{2}=0.0203\right)$ and $\mathrm{X} \mid(\mathrm{y}=0.05 \mathrm{x}-0.0033) \quad\left(\mathrm{p}>0.05, \mathrm{R}^{2}=0.0404\right)$. The relation between the otolith mass difference $(\mathrm{mr}$ $\mathrm{ml}$ ), and the fish length is more complex than the relation between $X$ and the fish length $(n=43$, total length $=120-340 \mathrm{~mm}, \mathrm{p}>0.05, \mathrm{y}=0.05 \mathrm{X}-0.0028$, $\mathrm{R}^{2}=0.0560$ ) (Fig. 4C). For C. guineensis, the mean value of $\mathrm{X}$ is $0.0355+0.0233, \mathrm{n}=33$ (Fig. 5A) and the value of $|\mathrm{X}|$ is $0.0343 \pm 0.0152, \mathrm{n}=33$ (Fig. $5 \mathrm{~B} 2$ ). According to the regression analysis, there was no relationship between the fish length, and both $X \quad(y=-0.0003 x+0.0103) \quad\left(p>0.005, \quad R^{2}=\right.$ $0.0001)$ and IXI $(y=0.0014 x-0.0184)\left(p>0.05, R^{2}=\right.$ $0.0117)$. The relation between otolith mass difference $(\mathrm{mr}-\mathrm{ml})$ and fish length is more complex than the relation between $x$ and fish length $(n=33$, total length $=120-340 \mathrm{~mm}, \mathrm{p}>0.05, \mathrm{y}=0.05 \mathrm{x}-$ $0.0007, \mathrm{R}^{2}=0.0016$ ) (Fig. 5C). In both species, the saccular otolith mass difference increases with the fish length.

\section{Otolith length and width asymmetry}

\section{Lake Ahémé}

The results of the asymmetry data analysis of the otolith length and width of $S$. melanotheron and C. guineensis are shown in the table 1. For both species, the results show that the level of asymmetry of the otolith width was the higher of the two values. The difference of the mean otolith length and width of both species in both localities $S$. melanotheron between both sides of the fish head in this lake were significant ( $\mathrm{t}$-test, $\mathrm{p}<0.05$ ). There were no differences in otolith sizes between males and females (t-test, $\mathrm{p}<0.05$ ) for this locality. For the two otolith characters studied in both species, the lowest and highest values of asymmetry are found in fish between 130-160 and 211-250 mm total length respectively, whereas the highest percentage of asymmetry was found in the otolith width for both species (Table 1). Individuals of $S$. melanotheron and $C$. guineensis were grouped in length classes (Table 2). The asymmetry values for the otolith length and width tend to increase as 


\begin{tabular}{|c|c|c|c|c|c|}
\hline & Character & $\mathrm{CV}_{\mathrm{a}}^{2}$ & $\mathrm{~N}$ & Character mean $\pm \mathrm{SD}$ & $\%$ of individuals with asymmetry \\
\hline \multirow{6}{*}{ Lake Ahémé } & \multicolumn{5}{|c|}{ Sarotherodon melanotheron } \\
\hline & Otolith length & 78.5 & 33 & $2.7234 \pm 0.6$ & $42 \%$ \\
\hline & Otolith width & 74.3 & 33 & $2.1102 \pm 0.3$ & $48 \%$ \\
\hline & \multicolumn{5}{|c|}{ Coptodon guineensis } \\
\hline & Otolith length & 80.2 & 33 & $2.6561 \pm 0.5$ & $58 \%$ \\
\hline & Otolith width & 82.3 & 33 & $2.2002 \pm 0.2$ & $62 \%$ \\
\hline \multirow{6}{*}{ Porto-Novo lagoon } & \multicolumn{5}{|c|}{ Sarotherodon melanotheron } \\
\hline & Otolith length & 95.4 & 43 & $3.66700 \pm 0.4$ & $76 \%$ \\
\hline & Otolith width & 96.3 & 43 & $2.1001 \pm 0.6$ & $79 \%$ \\
\hline & \multicolumn{5}{|c|}{ Coptodon guineensis } \\
\hline & Otolith length & 99.7 & 43 & $3.1223 \pm 0.3$ & $89 \%$ \\
\hline & Otolith width & 101.3 & 43 & $2.1334 \pm 0.7$ & $90 \%$ \\
\hline
\end{tabular}

Tabla 1. Valor del coeficiente cuadrado de asimetría $\left(\mathrm{CV}^{2}{ }_{\mathrm{a}}\right)$ y media del carácter $\left(\mathrm{X}_{\mathrm{r}+1}\right)$ de Sarotherodon melanotheron y Coptodon guineensis capturados en el Lago Ahémé y la laguna Porto-Novo (Benin)

Table 1. Squared coefficient of asymmetry $\left(\mathrm{CV}_{\mathrm{a}}^{2}\right)$ value and character means $\left(\mathrm{X}_{\mathrm{r}+1}\right)$ of Sarotherodon melanotheron and Coptodon guineensis collected from Lake Ahémé and Porto-Novo lagoon (Benin).

\begin{tabular}{|c|c|c|c|c|c|c|}
\hline & & Character & $\mathrm{CV}^{2}{ }_{\mathrm{a}}$ & $\mathrm{N}$ & Character mean & $\begin{array}{c}\% \text { of individuals with } \\
\text { asymmetry }\end{array}$ \\
\hline \multirow{20}{*}{ Lake Ahémé } & \multirow{10}{*}{ Sarotherodon melanotheron } & \multicolumn{5}{|c|}{ Otolith length } \\
\hline & & $130-160$ & 74.8 & 9 & $2.5 \pm 0.3$ & $0.9 \%$ \\
\hline & & $161-190$ & 75.2 & 11 & $2.5 \pm 0.6$ & $2.75 \%$ \\
\hline & & $191-220$ & 77.8 & 10 & $2.6 \pm 0.8$ & $2.0 \%$ \\
\hline & & $221-250$ & 78.1 & 3 & $2.8 \pm 0.2$ & $3 . \%$ \\
\hline & & \multicolumn{5}{|c|}{ Otolith width } \\
\hline & & $130-160$ & 70.2 & 9 & $2.0 \pm 0.3$ & $9.0 \%$ \\
\hline & & 161-190 & 73.1 & 11 & $2.1 \pm 0.8$ & $8.8 \%$ \\
\hline & & $191-220$ & 74.3 & 10 & $2.0 \pm 0.6$ & $10.0 \%$ \\
\hline & & $221-250$ & 75.2 & 3 & $2.2 \pm 0.2$ & $3.0 \%$ \\
\hline & \multirow{10}{*}{ Coptodon guineensis } & \multicolumn{5}{|c|}{ Otolith length } \\
\hline & & $130-160$ & 79.9 & 8 & $2.7 \pm 0.9$ & $8.0 \%$ \\
\hline & & $161-190$ & 80.1 & 10 & $2.6 \pm 0.8$ & $9.5 \%$ \\
\hline & & $191-220$ & 80.3 & 10 & $2.5 \pm 0.2$ & $10.0 \%$ \\
\hline & & $221-250$ & 80.4 & 5 & $2.6 \pm 0.3$ & $5.0 \%$ \\
\hline & & \multicolumn{5}{|c|}{ Otolith width } \\
\hline & & $130-160$ & 80.3 & 8 & $2.3 \pm 0.3$ & $8.0 \%$ \\
\hline & & $161-190$ & 81.7 & 10 & $2.2 \pm 0.8$ & $9.5 \%$ \\
\hline & & $191-220$ & 82.3 & 10 & $2.1 \pm 0.6$ & $9.5 \%$ \\
\hline & & $221-250$ & 84.2 & 5 & $2.4 \pm 0.2$ & $5.0 \%$ \\
\hline \multirow{28}{*}{ Porto-Novo lagoon } & \multirow{14}{*}{ Sarotherodon melanotheron } & \multicolumn{5}{|c|}{ Otolith length } \\
\hline & & $120-160$ & 94.5 & 5 & $3.7 \pm 0.3$ & $5.0 \%$ \\
\hline & & $161-200$ & 95.2 & 7 & $3.6 \pm 0.2$ & $6.65 \%$ \\
\hline & & $201-240$ & 97.7 & 9 & $3.4 \pm 0.8$ & $9.0 \%$ \\
\hline & & $241-280$ & 97.9 & 10 & $3.6 \pm 0.3$ & $9.5 \%$ \\
\hline & & $281-320$ & 98.2 & 9 & $3.5 \pm 0.2$ & $9.0 \%$ \\
\hline & & $321-360$ & 99.2 & 3 & $3.5 \pm 0.6$ & $3.0 \%$ \\
\hline & & \multicolumn{5}{|c|}{ Otolith width } \\
\hline & & $120-160$ & 94.1 & 5 & $2.1 \pm 0.8$ & $5.0 \%$ \\
\hline & & $161-200$ & 95.3 & 7 & $2.0 \pm 0.2$ & $7.0 \%$ \\
\hline & & $201-240$ & 95.6 & 9 & $2.1 \pm 0.3$ & $9.0 \%$ \\
\hline & & $241-280$ & 96.2 & 10 & $2.1 \pm 0.8$ & $9.5 \%$ \\
\hline & & $281-320$ & 96.5 & 9 & $2.1 \pm 0.9$ & $9.0 \%$ \\
\hline & & $321-360$ & 96.9 & 3 & $2.1 \pm 0.6$ & $3.0 \%$ \\
\hline & \multirow{14}{*}{ Coptodon guineensis } & \multicolumn{5}{|c|}{ Otolith length } \\
\hline & & $120-160$ & 97.2 & 5 & $3.1 \pm 0.3$ & $5.0 \%$ \\
\hline & & $161-200$ & 97.6 & 7 & $3.0 \pm 0.8$ & $6.65 \%$ \\
\hline & & $201-240$ & 98.4 & 9 & $3.3 \pm 0.2$ & $8.55 \%$ \\
\hline & & $241-280$ & 98.5 & 10 & $3.2 \pm 0.3$ & $9.5 \%$ \\
\hline & & $281-320$ & 99.2 & 9 & $3.3 \pm 0.8$ & $9.0 \%$ \\
\hline & & $321-360$ & 99.6 & 3 & $3.2 \pm 0.6$ & $3.0 \%$ \\
\hline & & \multicolumn{5}{|c|}{ Otolith width } \\
\hline & & $120-160$ & 98.2 & 5 & $2.0 \pm 0.2$ & $5.0 \%$ \\
\hline & & $161-200$ & 98.6 & 7 & $2.0 \pm 0.3$ & $7.0 \%$ \\
\hline & & $201-240$ & 99.5 & 9 & $2.1 \pm 0.2$ & $8.55 \%$ \\
\hline & & $241-280$ & 99.7 & 10 & $2.1 \pm 0.6$ & $9.5 \%$ \\
\hline & & $281-320$ & 99.9 & 9 & $2.1 \pm 0.8$ & $9.0 \%$ \\
\hline & & $321-360$ & 100.5 & 3 & $2.2 \pm 0.3$ & $3.0 \%$ \\
\hline
\end{tabular}

Tabla 2. Valor del coeficiente cuadrado de asimetría $\left(\mathrm{CV}^{2}{ }_{\mathrm{a}}\right)$ y media del carácter $\left(\mathrm{X}_{\mathrm{r}+1}\right)$ por clase de edad de Sarotherodon melanotheron y Coptodon guineensis capturados en el Lago Ahémé y la laguna Porto-Novo (Benin)

Table 2. Squared coefficient of asymmetry $\left(\mathrm{CV}_{\mathrm{a}}^{2}\right)$ value and character means $\left(\mathrm{X}_{\mathrm{r}+1}\right)$ by size class of of Sarotherodon melanotheron and Coptodon guineensis collected from Lake Ahémé and Porto-Novo lagoon (Benin). 
the fish grows and this for both species.

\section{Porto-Novo Lagoon}

The results of the asymmetry data analysis of the otolith length and width of $S$. melanotheron and C. guineensis in Porto-Novo Lagoon are shown in the table 1, they are similar to those obtained for Lake Ahémé. For the two otolith characters studied in both species, the lowest and highest values of asymmetry are found in fish between 120-60

A

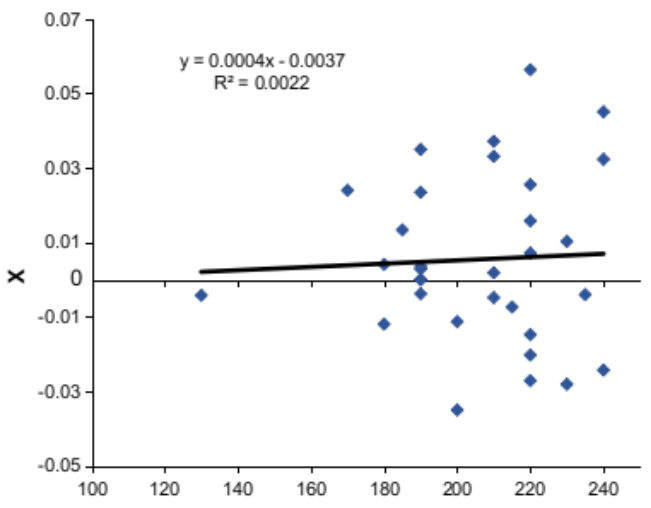

B

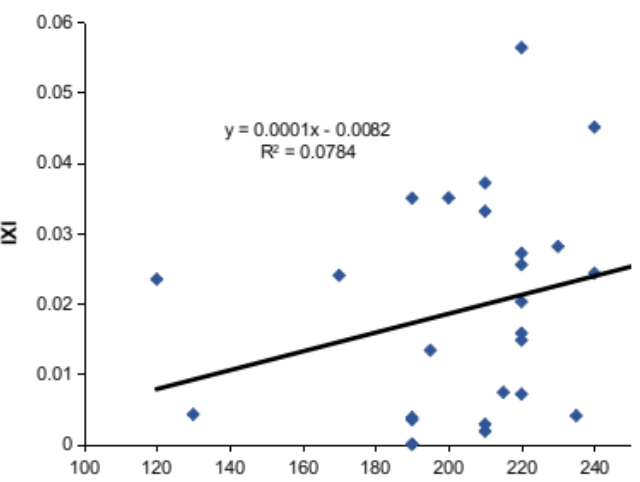

C

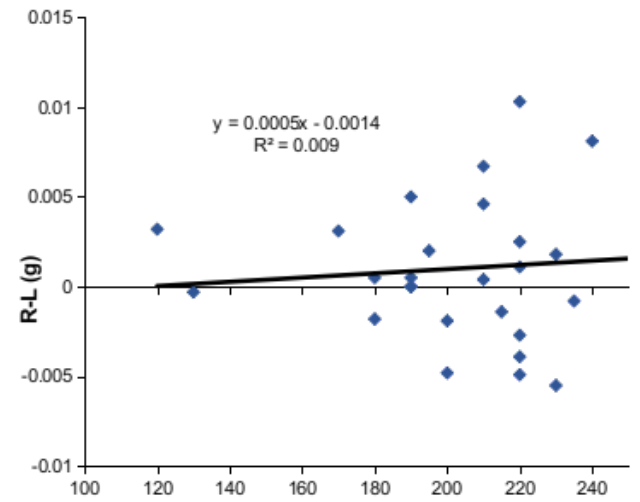

Figura 2. Masa del otolito sacular de Sarotherodon melanotheron capturados en el lago Ahémé en función de la longitud total del pez. A: Asimetría de la masa (X); B: Asimetría absoluta de la masa $(|\mathrm{X}|)$; $\mathbf{C}$ : Diferencia de la masa.

Figure 2. Saccular otolith mass of Sarotherodon melanotheron collected from Lake Ahémé as a function of the fish total length. A: Mass asymmetry (X); B: Absolute asymmetry ( $|\mathrm{X}|)$; C: Mass difference. $\mathrm{R} \& \mathrm{~L}=$ right and left side otolith mass. and $321-360 \mathrm{~mm}$ total length respectively, whereas the highest percentage of asymmetry was found in the otolith width for both species (Table 1). Individuals of $S$. melanotheron and $C$. guineensis were grouped in length classes (Table 2). The asymmetry values for the otolith length and width tend to increase as the fish grows and this for both species. There were no differences in otolith weight and sizes between males and females for this locality (t-test, $\mathrm{p}>0.05$ ).
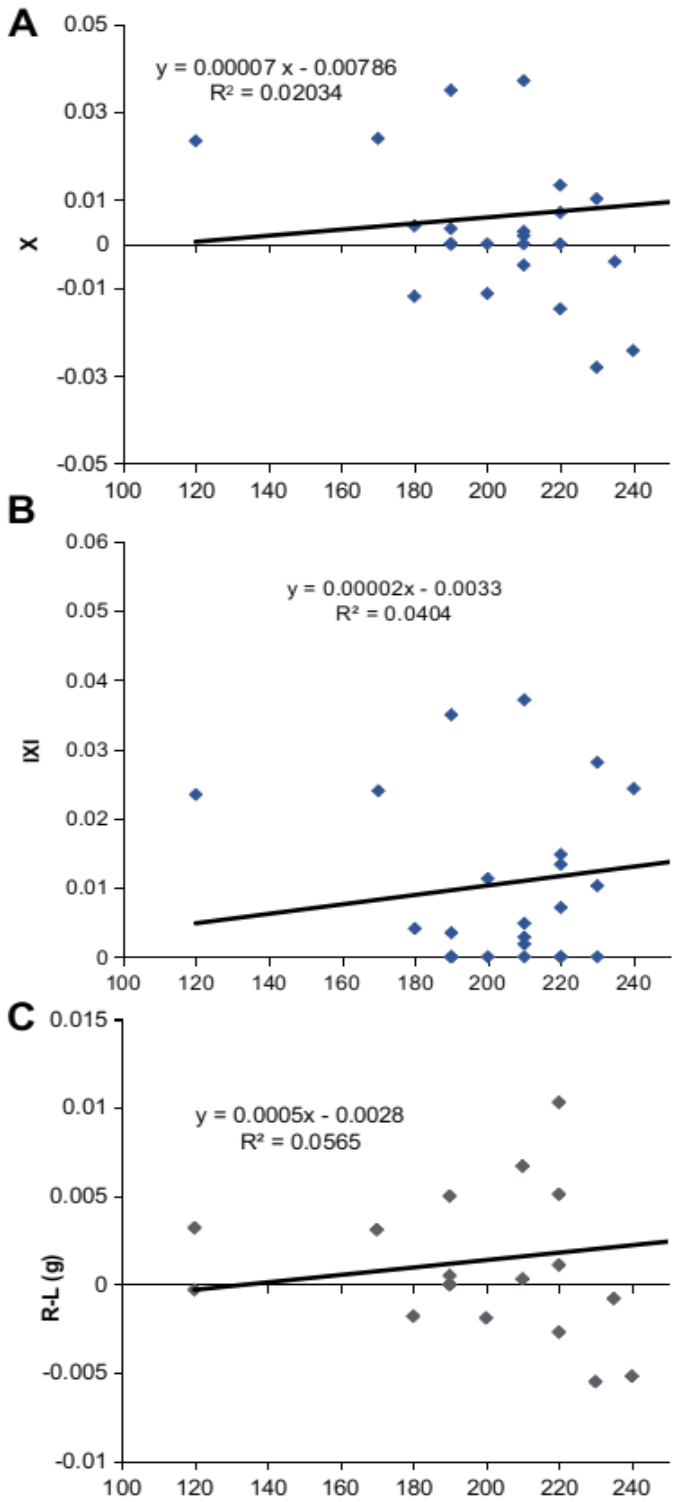

Figura 3. Masa del otolito sacular de Coptodon guineensi capturados en el lago Ahémé en función de la longitud total del pez. A: Asimetría de la masa (X); B: Asimetría absoluta de la masa $(|\mathrm{X}|)$; $\mathbf{C}$ : Diferencia de la masa.

Figure 3. Saccular otolith mass of Coptodon guineensis collected from Lake Ahémé as a function of the fish total length. A: Mass asymmetry $(\mathrm{X})$; B: Absolute asymmetry (|X|); C: Mass difference. $\mathrm{R} \& \mathrm{~L}=$ right and left side otolith mass. 

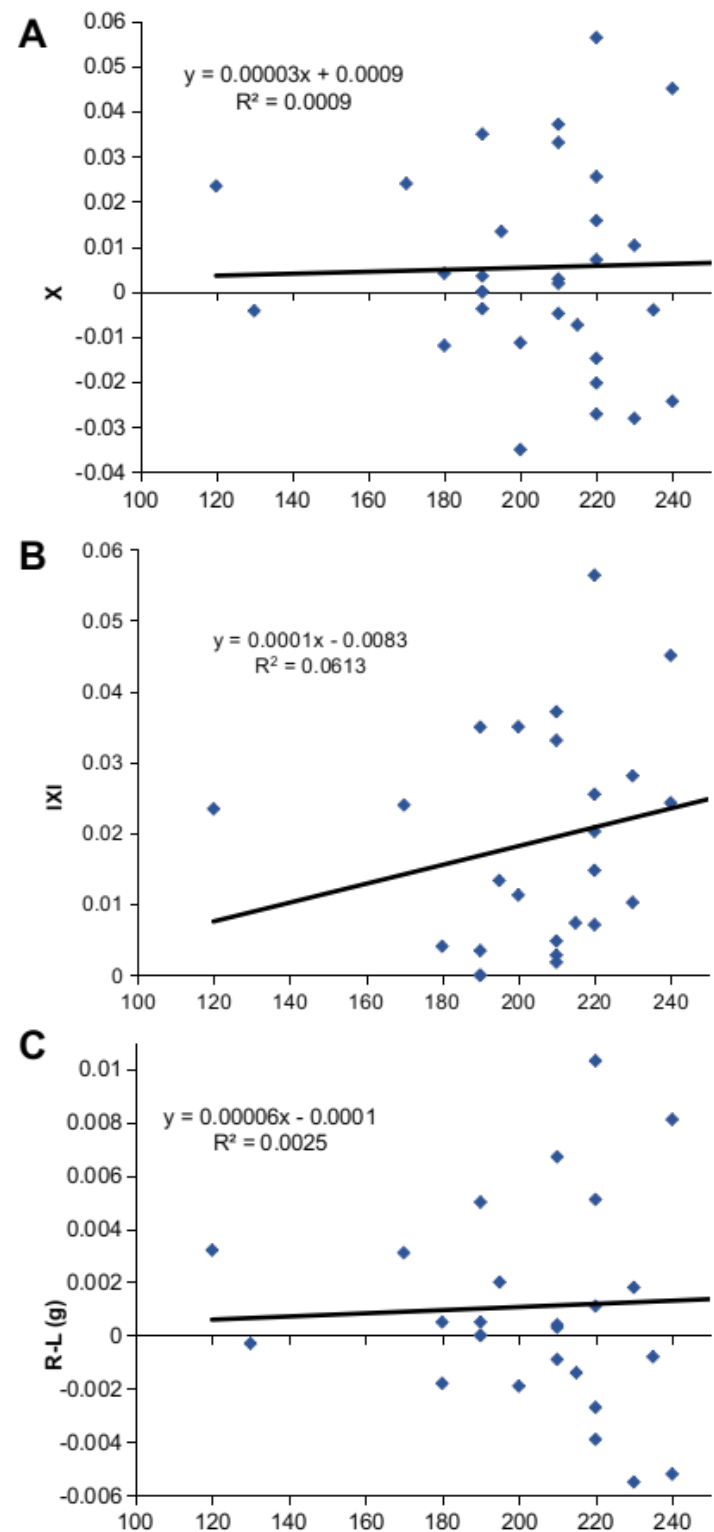

Figura 4. Masa del otolito sacular de Sarotherodon melanotheron capturados en laguna de Porto Novo en función de la longitud total del pez. A: Asimetría de la masa (X); B: Asimetría absoluta de la masa $(|\mathrm{X}|) ; \mathbf{C}$ : Diferencia de la masa.

Figure 4. Saccular otolith mass of Sarotherodon melanotheron collected from Porto-Novo Lagoon as a function of the fish total length. A: Mass asymmetry (X); B: Absolute asymmetry (|X|); C: Mass difference. $\mathrm{R} \& \mathrm{~L}=$ right and left side otolith mass.

\section{Discussion}

The otolith mass asymmetry in freshwater fish species has not been investigated well as in the marine species. In certain studies (Scherer et al. 2001, Takabayashi \& Ohmura-Iwasaki 2003), otolith mass asymmetry was covered as a secondary aim of the investigation by the scientist. The main result obtained by these studies that there are either small differences in mass of the left and
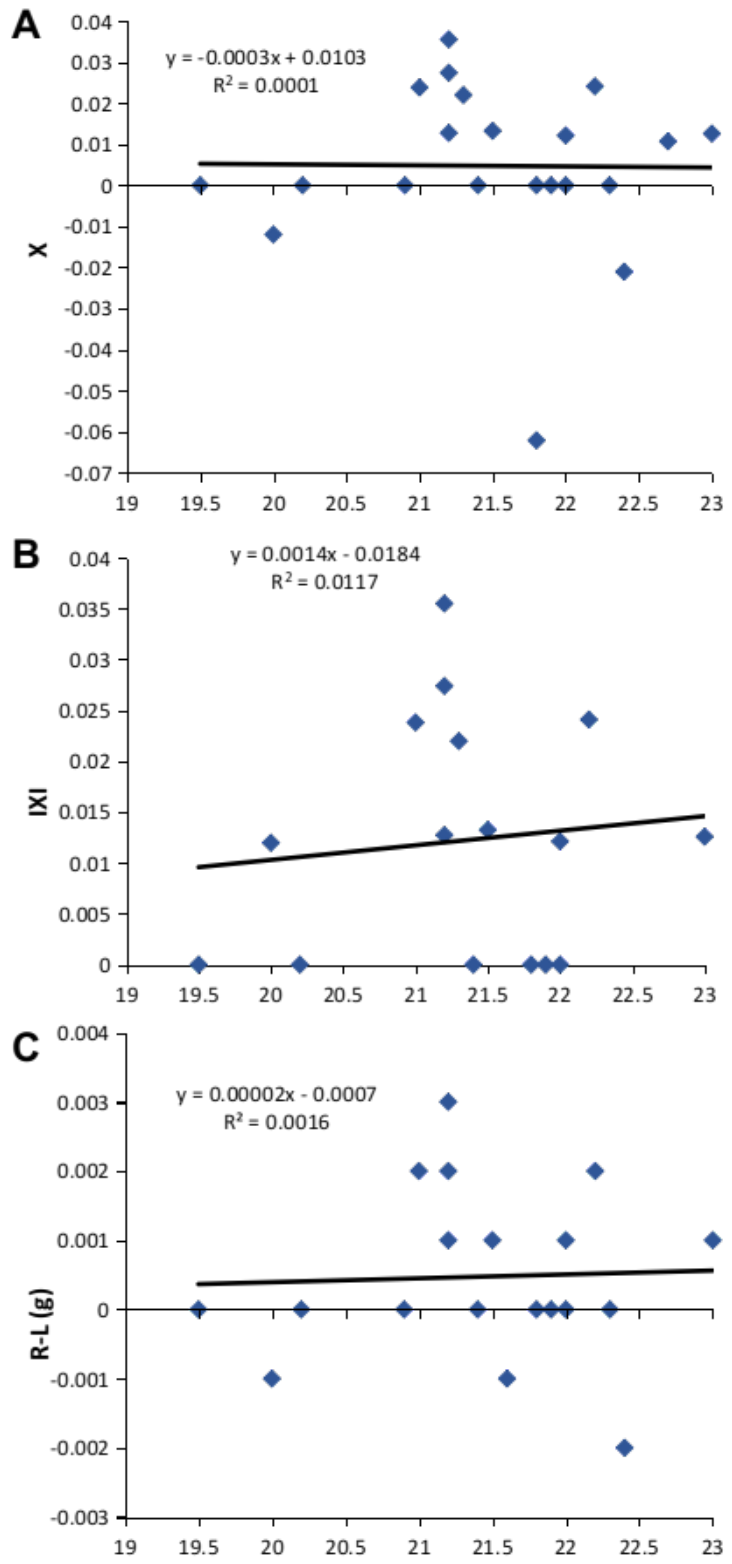

Figura 5. Masa del otolito sacular de Coptodon guineensis capturados en laguna de Porto Novo en función de la longitud total del pez. A: Asimetría de la masa (X); B: Asimetría absoluta de la masa $(|\mathrm{X}|)$; C: Diferencia de la masa.

Figure 5. Saccular otolith mass of Coptodon guineensis collected from Porto-Novo Lagoon as a function of the fish total length. A: Mass asymmetry $(\mathrm{X})$; B: Absolute asymmetry $(|\mathrm{X}|)$; C: Mass difference. $\mathrm{R} \& \mathrm{~L}=$ right and left side otolith mass.

right otoliths of the fish (Scherer et al. 2001) or small differences as it has been observed by Takabayashi \& Ohmura-Iwasaki (2003). The results obtained in the present study showed that there is a large difference between the mass of the otolith found on the left and right sides of the fish head of the species in question. This backs the finding of Scherer et al. (2001) on trout, salmon and Xiphophorus helleri Heckel, 1848. They suggested that the fish individuals with high otolith 
mass asymmetry showed an abnormal swimming compared to those with normal otolith. It is not possible to compare our results with those of Takabayashi \& Ohmura-Iwasaki (2003) as the later have used asteriscus and lapillus otolithes in their study rather than sagittae. This is because the fish species they investigated are belong to the family Cyprinidae, where the sagitta is smaller than both the asteriscus and lapillus. The results of the work at hand is complete agreement with that of Lychakov et al. (2008) on different fish species both freshwater and marine. They obtained a mathematical model showed that relatively large values of otolith mass asymmetry in fishes, which they suggested can affect acoustic performance and may be accountable for irregular fish swimming behavior. They also found that the value of $\mathrm{X}$ did not be influenced by fish size (length or mass), systematic or ecological position of the fish. Their results showed that in the bulk they studied, the saccular otolith $\mathrm{X}$ was small $|\mathrm{X}|<0.05$ (or $<5 \%$ ). Mathematical modeling indicates that values of $\mathrm{X}$ vary among individual fish, but that the value is probably stable during a fish's lifetime.

Since there are no similar studies on freshwater fish species like those obtained in the investigation at hand, it preferable to compare them with those results obtained from marine fish species. This will aid the readers to compare otolith mass asymmetry of freshwater and marine species.

Lychakov et al. (2006) suggested that otolith mass asymmetry shows similarities and differences among the marine roundfishes and flatfishes (Lychakov et al. 2008). They concluded that the saccular otolith mass asymmetry is not influenced by the fish length or the otolith growth rate.

As in other marine fish (Lychakov et al. 2008), the value of $X$ attained in the present study falls between -0.2 and +0.2 . The saccular otolith mass asymmetry, however, was less than 0.05 , a value that concurs with that obtained for a large number of marine species (Lychakov et al. 2006). The saccular otolith mass difference increases with the fish length as is the case for other fish species (Lychakov \& Rebane 2004). Lychakov \& Rebane (2004, 2005) showed in their mathematical model that the acoustic and vestibular functionality of a fish ear can decrease due to otolith mass asymmetry. Nevertheless, in the majority of fish species (Lychakov et al. 2006), including those studied, the saccular otolith mass asymmetry is very low
$(|X|<0.5)$, regardless of the fish length. This low level of otolith asymmetry is characteristic of the utricular and lagenar otoliths. By contrast, Lychakov \& Rebane (2005) showed that only fish with the largest otoliths and $|\mathrm{X}|>0.2$ could, in theory, have problems with sound processing due to the unsuitability and incongruity of the movement of the two otoliths on both sides of the head. Therefore, most teleost species can evade a functional disability as they have an otolith mass asymmetry below the critical value.

The effect of otolith mass asymmetry on the vestibular function was studied and explained by Lychakov \& Rebane $(2000,2004)$ in their mathematical model that showed the response of the ellipsoid-shaped otolith to the action of the force of gravity. They calculated the difference between the static displacement of the right and left ellipsoid-shaped otoliths and found that it depends on the otolith mass asymmetry. Such a displacement difference, they concluded, can be the chief cause of the different discharge features of the paired otolithic organs and hence the functional otolith asymmetry.

The results acquired in the present study of the saccular otolith mass asymmetry in S. melanotheron and $C$. guineensis show that it does not depend on the fish size. This agrees with the results gained by other researchers on several marine and freshwater fish species (Lychakov \& Rebane 2004, 2005, Lychakov et al. 2006, Jawad 2013, Jawad \& Sadighzadeh 2013, Jawad et al. 2011, 2012a, 2012b). However, the relationship between otolith mass difference and fish length is more complex. In the present work, no association between fish length and otolith mass has been found. This is in support with the results attained by Lychakov \& Rebane $(2004,2005)$ on several teleost species. Lychakov et al. (2006) suggested that an unproved connection could be due to the small sample used in the study or when specimens do not visibly diverge in size. Both suggestions can be applied to our dataset as only 33 (S. melanotheron) and 43 specimens (C. guineensis) with total lengths between 130-250 and 120-360 mm LT were used.

Otolith mass asymmetry can negatively impact the life of a fish, so the study of asymmetry is very vital. In the present study, the average otolith mass asymmetry of $S$. melanotheron and $C$. guineensis from the two localities was lower than that obtained on an individual basis. These results 
show that both populations of the two species are under environmental stress. It has been found that the otolith mass asymmetry of $S$. melanotheron and C. guineensis in Lake Ahémé is higher than that in Porto-Novo Lagoon. Therefore, it may be extrapolated that populations of both species in Lake Ahémé are more subjected to pollution or other factors originating from the stress, and this is reflected by the otolith mass asymmetry of the fish. Additional investigations with larger numbers of specimens and a wider range of body size are essential to explore the association between the otolith mass difference and the fish length, especially in view of the absence of studies on otolith mass asymmetry in Benin. This study is offers a starting point for future studies in marine and freshwater fish species in Benin and will allow researchers to make associations between species in Benin and species living in the adjacent areas.

We found that the level of asymmetry is the highest in the otolith width for both $S$. melanotheron and $C$. guineensis ranging in length between $130-250$ and $120-360 \mathrm{~mm}$ LT and this at both sampling sites. Moreover, the asymmetry values of the length and width of the otolith were higher in Porto-Novo Lagoon than in Lake Ahémé for both species.

A large bilateral asymmetry value for otolith width has earlier been recorded in several fish species (Jawad et al. 2012c), which could have to do with the susceptibility of the otolith width to immediate fluctuations in the environment. Therefore, this value could be used as an actual biomarker of stress in the environment. By contrast, the otolith length showed lower bilateral asymmetry values in both species examined, which suggests that this character may be less subjected to environmental stress factors, including pollution. Alternatively, this lower bilateral asymmetry value may be explained by the fact that the developmental period of otolith length may not concur with the presence of adverse environmental events (Jawad 2003).

The obvious effect of bilateral asymmetry in fish otoliths is the abnormal swimming activity (Helling et al. 2003) and interference with correct sound localization resulting in the inability of individuals to integrate with the habitat they are living in (Lychakov \& Rebane 2005). The capability of young individuals of $S$. melanotheron and C. guineensis to find and settle down in a suitable environment can be hindered by the variations in the dimensions of the otolith (Gagliano \& McCormick 2004, Gagliano et al. 2008). Thus, the settlement of the larvae of the species studied in the present work might be affected by the asymmetry in the morphological characters of their otoliths.

The low bilateral asymmetry value in otolith size at Lake Ahémé can be regarded as usual since biological systems cannot have a perfect bilateral symmetry even in a perfect environment. Minor inconsistencies during development can occur in normal developmental processes (Palmer \& Strobeck 1992). These anomalies may be due to the quality and quantity of food, extreme temperatures, parasites, disease and behavioral stress forced by relations with conspecifics (Markov 1995).

Due to the lack of data regarding the natural asymmetry in Benin, it is impossible to evaluate the level of asymmetry of the two morphological characters of the otolith of $S$. melanotheron and C. guineensis and to determine whether they are higher or lower than average.

The analysis of variance reveals that bilateral asymmetry values for the otolith mass, length and width, differs significantly between $S$. melanotheron and $C$. guineensis from Porto-Novo Lagoon and Lake Ahémé $(p<0.001)$. There is a noteworthy level of pollution by different types of contaminants such as organic pollutants and heavy metals in the areas where fish were collected at both localities (Yèhouénou et al. 2013). It is likely that pollution may be responsible for the high bilateral asymmetry values in these areas as frequent studies have confirmed (Elie \& Girard 2014). Overall, the levels of toxicity by several trace metals and chemicals is known to upsurge with the increase in both temperature and salinity (Kwok \& Leung 2005, Elie \& Girard 2014). The average water temperature of both water bodies is similar $\left(28^{\circ} \mathrm{C}\right)$, does not help in understanding the role of the water temperature in an environment of growing toxicity. By contrast, the salinity as a factor enhancing the toxicity by pollutants can be taken into consideration in this case, because the salinity level of Porto Novo Lagoon $(>28 \mathrm{~g} / \mathrm{l})($ Gnohossou 2006) is higher than that of Lake Ahémé (<5 g/l) (Niyonkuru 2007).

Developmental disarrays from chemical and organic pollution can lead to severe morphological deformities (Bengtsson et al. 1988). In the two 
localities studied, fish abnormalities were reported, related to heavy metal and organic pollution, in addition to a bilateral asymmetry detected in some morphological characters of both species (Jawad et al. 2016).

As shown in preceding investigations (AlMamry et al. 2011a, 2011b, Jawad et al. 2012a, 2012b, 2012c, Mabrouk et al. 2014), the ANOVA test analysis in the current study reveals that large specimens of $S$. melanotheron and C. guineensis at the two localities have higher bilateral asymmetry values than smaller, younger specimens $(\mathrm{p}<$ $0.001)$. It was obvious that the values of fluctuating bilateral asymmetry of the two otolith dimensions, length and width, increased with fish size in both species (Table II). This tendency of increase in the otolith dimensions is probably due to due to the result of imperfect development (Valentine et al. 1973). Similar results were attained by Valentine et al. (1973), who advocated two possible hypotheses to support such a trend: ontogenetic changes linked to an increase in bilateral asymmetry with size (age) or possible historical processes which result in a secular increase in bilateral asymmetry. However, Thiam (2004) proposed that an increasing tendency of bilateral asymmetry values with fish size may be due to the fact that large size individuals had longer periods of contact with adverse environmental situations and therefore lost their steadiness in such environments. Further studies are needed to support either the suggestion of Valentine et al. (1973) or Thiam (2004).

An administration plan is immediately essential in order to reinstate a healthy environment in both Porto-Novo Lagoon and Lake Ahémé. Numerous aquatic plant and animal species within these water bodies have already been harmfully affected (Gnohossou 2006).

\section{Acknowledgements}

The authors thank Kristiaan Hoedemakers, Royal Belgian Institute of Natural Sciences (RBINS), Vautierstraat 29, B-1000 Brussels, Belgium for reading the manuscript.

\section{References}

Adandédjan D, Lalèyè $P$, Ouattara A \& Gourene G.
2011. Distribution of benthic insect fauna in a West African lagoon: the Porto-Novo Lagoon in Bénin. Asian Journal of Biological Science 4: 116-127.

Alemany F \& Alvarez F. 1994. Formation of initial daily increments in sagittal otoliths of reared and wild Sardina pilchardus yolk-sac larvae. Marine Biology 121: 35-39.

Al-Mamry J, Jawad L, Al-Bimani S, Al-Ghafari F, AlMamry D \& Al-Marzouqi M. 2011a. Asymmetry in some morphological characters of Leiognathus equulus (Forsskål)(Leiognathidae) collected from the Sea of Oman. Archives of Polish Fisheries 19: 5155.

Al-Mamry JM, Jawad LA, Al-Bimani SMH, Al-Busaidi HK, Al-Marzouqi MS \& Al-Habsi SH. 2011b. Asymmetry analysis study on Callionymus margaretae Regan, 1906 collected from the Arabian Sea coasts of Oman. Croatian Journal of Fisheries: Ribarstvo 69: 9-9.

Anken RH, Werner K, Ibsch M \& Rahmann H. 1998. Fish inner ear otolith size and bilateral asymmetry during development. Hearing Research 121: 77-83.

Bao B, Ke Z, Xing J, Peatman E, Liu Z, Xie C, Xu B, Gai J, Gong X, Yang G \& Jiang Y. 2011. Proliferating cells in suborbital tissue drive eye migration in flatfish. Developmental Biology 351: 200-207.

Bengtsson BE. 1988. Effects of pulp mill effluents on skeletal parameters in fish-a progress report. Water Science Technology 20: 87-94.

Dissou M. 1986. La republique Populaire du Bénin: Milieux naturels, régions, économie agricole régionale. Première Partie: le Bas-Bénin. Project UNB/UVA/ ER, Abomey- Calavi (Bénin).

Downhower JF, Blumer LS, Lejeune PI, Gaudin P, Marconato A \& Bisazza A. 1990. Otolith asymmetry in Cottus bairdi and C. gobio. Polish Archieve of Hydrobiology 37: 209-220.

Elie P \& Girard P. 2014. La santé des poissons sauvages: les codes pathologie, un outil d'évaluation. Montpellier, France: Association Santé Poissons Sauvages.

Froese R \& Pauly D. (eds.) 2018. FishBase, version $06 / 2015$. Available at www.fishbase.org (accessed September 2018).

Gagliano M \& McCormick MI. 2004. Feeding history influences otolith shape in tropical fish. Marine Ecology Progress Series 278: 291-296

Gagliano M, Depczynski M, Simpson SD \& Moore JA. 2008. Dispersal without errors: symmetrical ears tune into the right frequency for survival. Proceedings of the Royal Society of London B: Biological Sciences 275: 527-534.

Gnohossou P. 2006. La faune benthique d'une lagune Ouest Africaine le lac Nokoué au Bénin, diversité, abondance, variations temporelles et spatiales, place dans la chaîne trophique. France: Ecole Nationale Supérieure Agronomique de Toulouse (INP-ensat). Doctoral Thesis.

Grønkjær P \& Sand MK. 2003. Fluctuating asymmetry and nutritional condition of Baltic cod (Gadus morhua) larvae. Marine Biology 143: 191-197.

Helling K, Hausmann S, Clarke A, Scherer H. 2003. Ex- 
perimentally induced motion sickness in fish: possible role of the otolith organs. Acta otolaryngolica 123: 488-492.

Jawad LA. 2003. Asymmetry in some morphological characters of four sparid fishes from Benghazi, Libya. Oceanological Hydrobiological Studies 32: 83-88.

Jawad LA. 2013. Otolith Mass Asymmetry in Carangoides caerulepinnatus (Rüppell, 1830 (Family: Carangidae) Collected from the Sea of Oman. Croatian Journal of Fisheries 71: 37-41.

Jawad LA \& Sadighzadeh Z. 2013. Otolith mass asymmetry in the mugilid fish, Liza klunzingeri (Day, 1888) collected from Persian Gulf near Bandar Abbas. Anales de Biologia 35: 105-107.

Jawad L A, Al-Mamry J M, Al-Mamari D \& Al-Hasani L. 2012a. Study on the otolith mass asymmetry in Lutjanus bengalensis (Family: Lutjanidae) collected from Muscat City on the Sea of Oman. Journal of Fisheries Science 6: 74-79.

Jawad L, Al-Mamry J \& Al-Mamary D. 2012c. Fluctuating asymmetry in the otolith dimensions of Lutjanus bengalensis (Lutjanidae) collected from Muscat coast on the sea of Oman. Biological Journal of Armenia 64: 117-121.

Jawad LA, Al-Mamry JM, Al-Mamari HM, Al-Yarubi MM, Al-Busaidi HK \& Al-Mamary DS. 2011. Otolith mass asymmetry in Rhynchorhamphus georgi (Valenciennes, 1846)(Family: Hemiramphidae) collected from the Sea of Oman. Journal of Black Sea/Mediterranean Environment 17.

Jawad LA, Mehanna S F, El-Regal M A, Ahmed Y A. 2012b. Otolith Mass Asymmetry in Two Parrotfish Species, Chlorurus sordidus (Forsskål, 1775) and Hipposcarus harid (Forsskål, 1775) from Hurghada, Red Sea Coast of Egypt. International Journal of Marine Science 7: 200-204.

Jawad L, Gnohossou P \& Tossou AG. 2016. Bilateral asymmetry in certain morphological characters of Sarotherodon melanotheron Rüppell 1852 and Coptodon guineensis (Günther 1862) collected from Lake Ahémé and Porto-Novo Lagoon Bénin, West Africa. Marine Pollution Bulletin 103: 39-44.

Kingsmill S. 1993. Ear stones speak volumes to fish researchers. Science 260: 1233-1 234.

Kottelat M. 1985. Freshwater fishes of Kampuchea. Hydrobiologia 121: 249-279.

Kullander SO \& Nijssen H. 1989. The Cichlids of Surinam (Teleostei, Labroidei). Leiden, Netherlands: E.J. Brill.

Kwok KWH \& Leung KMY. 2005. Toxicity of antifouling biocides to the intertidal harpacticoid copepod Tigriopus japonicus (Crustacea, Copepoda): effects of temperature and salinity. Marine Pollution Bulletin 51: 830-837.

Lychakov DV \& Rebane YT. 2000. Otolith regularities. Hearing Research 143: 83-102.

Lychakov DV \& Rebane YT. 2004. Otolith mass asymmetry in 18 species of fish and pigeon. Journal of Gravity Physiology 11: 17-34.

Lychakov DV, Rebane YT, Lombarte A, Fuiman LA \& Takabayashi A. 2006. Fish otolith asymmetry: morphometry and modeling. Hearing Research 219: 1-11.

Lychakov DV \& Rebane YT. 2005. Fish otolith mass asymmetry: morphometry and influence on acoustic functionality. Hearing Research 201: 55-69.

Lychakov DV, Rebane YT, Lombarte A, Demestre M \& Fuiman LA. 2008. Saccular otolith mass asymmetry in adult flatfishes. Journal of Fish Biology 72: 25792594.

Mabrouk L, Guarred T, Hamza A, Messaoudi I \& Hellal AN. 2014. Fluctuating asymmetry in grass goby Zosterisessor ophiocephalus Pallas, 1811 inhabiting polluted and unpolluted area in Tunisia. Marine Pollution Bulletin 85: 248-251.

Markov TA. 1995. Evolutionary ecology and developmental instability. Annual Review of Entomology 40: 105-120.

Mille T, Mahe K, Villanueva M C, De Pontual H \& Ernande B. 2015. Sagittal otolith morphogenesis asymmetry in marine fishes. Journal of Fish Biology 87: 646-663.

Niyonkuru C. 2007. Etude comparée de l'exploitation et de la démographie des poissons Cichlidés dans les lacs Nokoué et Ahémé au Bénin (Thèse de Doctorat en Gestion de l'Environnement) Université d'Abomey-Calavi, Bénin (199 pp.).

Niyonkuru C \& Lalèyè P. 2012. A comparative ecological approach of the length-weight relationships and condition factor of Sarotherodon melanotheron Rüppell, 1852 and Tilapia Guineensis (Bleeker 1862) in Lakes Nokoué and Ahémé (Bénin, West Africa). International Journal of Business and Human Technology 2: 41.

Novak M, Abdoli A, Pont D \& Sagnes P. 2013. Otolith asymmetry as a proxy of thermal stress in cold water fish: do observations on natural populations of Cottus gobio meet experimental results? Cybium 37: 281-284.

Østbye K, Øxnevad SA \& Vøllestad LA. 1997. Developmental stability in perch (Perca fluviatilis) in acidic aluminium-rich lakes. Canadian Journal of Zoology 75: 919-928.

Øxnevad SA, Heibo E \& Vøllestad LA. 2002. Is there a relationship between fluctuating asymmetry and reproductive investment in perch (Perca fluviatilis)? Canadian Journal of Zoology 80: 120-125.

Palmer AR \& Strobeck C. 1992. Fluctuating asymmetry as a measure of developmental stability: implications of non-normal distribution and power of stability tests. Acta Zoologica Fennica 191: 57-72.

Panfili J, De Pontual H, Troadec H \& Wright PJ (Eds.). 2002. Manual of fish sclerochronology. Brest, France: Ifremer-IRD coedition.

Popper AN \& Lu Z. 2000. Structure-function relationships in fish otolith organs. Fisheries Research 46: 15-25.

Scherer H, Helling K, Clarke AH \& Hausmann S. 2001. Motion sickness and otolith asymmetry. Biological Sciences in Space 15: 401-404.

Takabayashi A \& Ohmura-Iwasaki T. 2003. Functional asymmetry estimated by measurements of otolith in fish. Biological Sciences in Space, 17: 293-297. 
Thiam N. 2004. Ecomorphologie de Trisopterus luscus (Linnaeus, 1758) tacaud, adaptation a la température at l'asymmétric fluctuante (Ph.D. Thesis) Faculté des Sciences, Université de Vigo (190 pp.).

Valentine DW, Soule ME \& Samollow P. 1973. Asymmetry in fishes: a possible statistical indicator of environmental stress. Fishery Bulletin 71: 357-370.

Welcomme RL. 1988. International introductions of inland aquatic species. Rome: FAO Fisheries Department.

Yamamoto MN. 1992. Occurrence, distribution and abundance of accidentally introduced freshwater aquatic organisms in Hawaii. State of Hawaii, Fe- deral Aid in Sportfish Restoration, Dingell-Johnson JOR. Freshwater Fisheries Research and Surveys, Projects No. F-14-R-16.

Yedier S, Bostanci D, Kontaş S, Kurucu G \& Polat N. 2018. Comparison of otolith mass asymmetry in two different Solea solea populations in Mediterranean sea. Ordu University Journal of Science and Technology 8(1): 125-133.

Yèhouénou A, Azéhoun R, Edorh PA \& Ahoyo T. 2013. Monitoring of heavy metals in the complex "Nokoué lake-Cotonou and Porto-Novo lagoon" ecosystem during three years in the Republic of Benin. Research Journal of Chemical Science 3: 12-18. 